\title{
Evaluation of the Risk Factors Associated with Dislocation Following Cementless Bipolar Hemiarthroplasty of the Hip in Elderly Patients: A Nested Case-Control Study
}

\author{
Yașlı Hastalarda Çimentosuz Bipolar Kalça Hemiartroplastisi Sonrası Çıkık Gelișimi ile \\ İlișkili Risk Faktörlerinin Değerlendirilmesi: Yuvalandırılmış Olgu Kontrol Çalıșması \\ (D) Fevzi Birişik1, (D) Mehmet Demirel2, (D) Yücel Bilgin1, (D) Yusuf Öztürkmen1 \\ 1 University of Health Sciences Turkey, Istanbul Training and Research Hospital, Clinic of Orthopaedics and Traumatology, Istanbul, Turkey \\ ${ }^{2}$ Yüksekova State Hospital, Clinic of Orthopedics and Traumatology, Hakkari, Turkey
}

\begin{abstract}
Introduction: Although a well-known advantage of the cementless fixation technique is that it prevents bone cement implantation syndrome, with lower perioperative mortality, the risk factors associated with dislocation after cementless bipolar hemiarthroplasty (BHA) have not yet been sufficiently investigated. This study aimed to investigate the incidence of dislocation following cementless BHA of the hip in elderly patients with displaced femoral neck fractures. The related risk factors are also examined.

Methods: In this nested case-control study, patients who had undergone BHA for femoral neck fracture at a single tertiary referral center were retrospectively reviewed. Three control patients from the cohort who had not experienced dislocation were selected for each patient who developed dislocation following BHA. Clinical and radiographic outcome measures were then assessed to determine the risk factors for dislocation following BHA.

Results: Of the 103 patients available for the analyses in the current study, 23 patients (12 females, 11 males) with dislocation were selected as the study group and 70 patients (33 females, 37 males) without dislocation were included in the control group. Univariate analyses revealed significant differences between the two groups in terms of number of postoperative surgical site infections, dementia, centeredge angle, and femoral offset. Two independent risk factors associated with dislocation, namely, infection and dementia, were identified during multivariate model analysis.

Conclusion: Patients with postoperative surgical site infection or dementia are at greater risk for developing dislocation after cementless BHA.
\end{abstract}

Keywords: Cementless bipolar hemiartrhoplasty, dislocation, risk factors, femoral neck fracture

\section{öZ}

Amaç: Çimentosuz fiksasyon tekniğinin iyi bilinen avantajları, düşük perioperatif mortalite ile kemik çimentosu implantasyon sendromunu önlemesi olmasına rağmen, çimentosuz bipolar hemiartroplasti (BHA) sonrası dislokasyona bağlı risk faktörleri henüz literatürde yeterince araştırılmamıştır. Bu çalışma, yer değiştirmiş femur boynu kırığı olan yaşlı hastalarda kalçanın çimentosuz BHA'sını takiben çıkık insidansını ve ilișkili risk faktörlerini araştırmayı amaçladı.

Yöntemler: Bu yuvalanmış olgu kontrol çalıșmasında, tek bir üçüncü basamak merkezde femur boyun kırığı nedeniyle BHA uygulanmış hastalar geriye dönük olarak incelendi. BHA'yı takiben çıkık gelişen her hasta için kohortlardan çıkık yaşamamış üç kontrol hastası seçildi. BHA sonrası dislokasyon gelişimi ile ilgili risk faktörlerini belirlemek adına çeșitli klinik ve radyografik sonuç ölçütleri değerlendirildi.

Bulgular: Analiz için uygun olduğu belirlenen toplam 103 hasta arasından dislokasyon geliștirmiș olan 23 hasta (12 kadın, 11 erkek) çalışma grubu olarak seçildi. Kontrol grubuna çıkık geliștirmemiş toplam 70 hasta (33 kadın, 37 erkek) dahil edildi. Tek değişkenli analizler, postoperatif cerrahi alan enfeksiyonlarının sayısı, demans, merkez kenar açısı ve femoral off-set açısından iki grup arasında önemli farklııklar ortaya koydu. Çok değişkenli model analizinde, dislokasyonla ilișkili iki bağımsız risk faktörleri olarak: Enfeksiyon ve demans tespit edildi.

Sonuç: Ameliyat sonrası cerrahi alan enfeksiyonu veya demansı olan hastalar çimentosuz BHA'dan sonra dislokasyon gelişme riski altındadır.

Anahtar Kelimeler: Çimentosuz bipolar hemiartroplasti, çıkık, risk faktörleri, femur boyun kırığı Control Study. İstanbul Med J 2021; 22(3): 208-12.

(c) Copyright 2021 by the University of Health Sciences Turkey, Istanbul Training and Research Hospital/Istanbul Medical Journal published by Galenos Publishing House. 
Birişik et al. Risk Factors for Dislocation after Hemiarthroplasty

\section{Introduction}

The incidence of femoral neck fractures has steadily increased along with the improvement of the average life expectancy and social activities of elderly patients $(1,2)$. The most common treatment options for patients with displaced femoral neck fractures include bipolar hemiarthroplasty (BHA) or total hip arthroplasty (THA); of these, BHA is cited as the most widely performed procedure in the treatment of these patients in the USA (1).

Compared with THA, BHA is a less invasive surgery characterized by lower blood loss, shorter operation times, and lower initial costs (3). One of the major causes of treatment failure following BHA is hip dislocation. The literature reports an incidence of dislocation ranging from $1 \%$ to $11 \%$, which indicates that this complication may be secondary to patientrelated factors, such as a history of neurological disease or weakness of the abductor muscles, or surgery-related factors, such as the choice of surgical approach and prosthesis type (4-8).

BHA prostheses can be implanted via the cemented or cementless techniques, and both approaches have comparable clinical results $(9,10)$. Although a well-known advantage of the cementless fixation technique is that it prevents bone cement implantation syndrome, with lower perioperative mortality $(11,12)$, to the best of our knowledge, the risk factors associated with dislocation after cementless BHA have not yet been sufficiently investigated. The aim of the present study, therefore, is to investigate the incidence of dislocation following cementless BHA of the hip in elderly patients with displaced femoral neck fractures. The related risk factors are also examined.

\section{Methods}

A retrospective chart review of patients who had undergone BHA for femoral neck fracture between 2012 and 2019 at a single tertiary referral center was conducted in this work. Written informed consent was obtained from all participants prior to their participation in this study. The inclusion criteria for the study were a diagnosis of unilateral femoral neck fracture due to low-energy trauma, treatment by cementless BHA, age of 65 years or older, a minimum of 1 year of follow-up, complete medical records and radiographic images, and willingness to participate in the study. The exclusion criteria included a diagnosis of femoral neck fracture due to high-energy trauma, pathological hip fracture, a history of polytrauma, a history of previous hip surgery, loss to follow-up, death during the first year of follow-up, and inadequate radiographic imaging.

\section{Study Population and Design}

A total of 241 patients were assessed according to the above eligibility criteria. Exclusion of 138 patients left 103 patients available for analysis in this study. A nested case-control design was used to analyze the risk of experiencing hip dislocation following BHA. Three control patients from the cohort who had not experienced dislocation were selected for each patient with dislocation on the basis of age ( \pm 3 years), gender, and time of surgery (the approximate ratio of 1:3 case-to-control). The approval form the University of Health Sciences Turkey, İstanbul Training and Research Hospital Local Ethics Committee was obtained (approval number: 2657, date: 08.01.2021).

\section{Surgical Technique}

All BHA procedures were performed via a standard posterior approach by four experienced orthopedic surgeons. A cementless bipolar prosthesis was implanted in all of the patients (F40, Biomet, Inc., Warsaw, IN, USA). A standard management protocol, including general or spinal anesthesia, thrombosis prophylaxis, a suitable perioperative antibiotic administration for infection prophylaxis, and physical rehabilitation, was used in all operations. Low-molecular weight heparin was administered as a thrombosis prophylaxis 12 hours prior to surgery and terminated as the patients gained full mobility. Full weight bearing was allowed immediately postoperatively if tolerated by the patients. All patients received a standardized rehabilitation program under the supervision of physiotherapists.

\section{Clinical Outcome Measures}

The length of time from hospital admission to operation, the length of hospital stay, the length of hospitalization in the intensive care unit (ICU), the time from operation to dislocation, the presence of postoperative surgical site infection, the type of anesthesia, any medical comorbidities, and the American Society of Anesthesiologists (ASA) score of each patient were obtained from the hospital database.

The type of anesthesia administered was categorized as regional or general. Medical comorbidities involved heart disorders (i.e., congestive heart failure, myocardial infarction), diabetes mellitus, chronic pulmonary disorders, and dementia. ASA scores were documented to assess the physical status of the patients upon admission (13).

\section{Radiographic Outcome Measures}

The acetabular abduction angle (AA), femoral offset (FO), center-edge (CE) angle, and limb length discrepancy (LLD) were measured from the first postoperative anteroposterior hip radiographs collected by an experienced orthopedic surgeon. AA $\left(^{\circ}\right)$ was calculated as the angle between the horizontal line passing through the ischial tuberosities and the line from the acetabular teardrop to the lateral acetabular margin. FO ( $\mathrm{mm}$ ) was calculated as the perpendicular distance between the axis of the femoral shaft and the center of rotation. LLD $(\mathrm{mm})$ was measured by calculating the difference in vertical distance from the inter-teardrop line to the lesser trochanter between both sides (Figure 1).

\section{Statistical Analysis}

IBM SPSS Statistics software version 20.0 (IBM Corp., Armonk, New York, NY, USA) was used for statistical analysis, and $p<0.05$ was regarded as statistically significant. Normality tests were conducted using the ShapiroWilk test. Data are presented as "minimum," "maximum," "median," "IQR" "arithmetic mean," "number," and "percentage." The data of the study group were converted to nested case-control data based on a 1:3 ratio of patients to controls. For univariate analyses, parametric data were compared by Student's t-test for normally distributed variables and the Mann-Whitney $U$ test for non-normally distributed ones. Nonparametric data were compared using the $\chi^{2}$ test or Fisher's exact test. For multivariate analyses, conditional logistic regression analyses were performed using a backward elimination technique to identify 


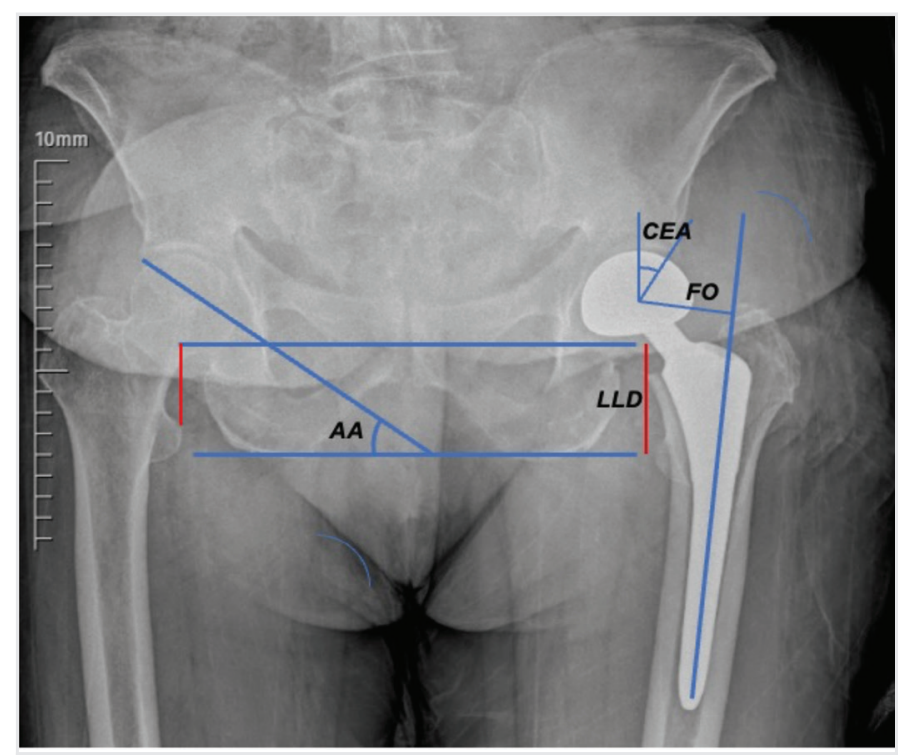

Figure 1. Measurements of center-edge angle, abduction angle, leg length discrepancy, and femoral offset

CEA: Center-edge angle, AA: abduction angle, LLD: leg length discrepancy, FO: femoral offset independent risk factors for the development of dislocation of hip BHA, with significant variables $(\boldsymbol{p}<0.25)$ as in univariate analyses.

\section{Results}

\section{Demographic Characteristics}

Of the 103 patients available for the analyses in the current study, 23 patients (12 females, 11 males) were chosen as the study group because they had experienced at least one dislocation following BHA (3 developed recurrent dislocations). A total of 70 patients ( 33 females, 37 males) who experienced no dislocation were included in the control group. The demographic characteristics of the study population are presented in Table 1. The mechanism of dislocation was atraumatic in 17 patients (74\%) and a simple fall in 6 patients (26\%).

\section{Univariate Analysis}

Table 2 summarizes the clinical and radiographic outcomes of both groups. Univariate analyses showed significant differences between the study and control groups with respect to the following outcome measures: number of postoperative surgical site infections, dementia, CE angle, and FO.

\section{Table 1. Demographic characteristics of the study participants}

\section{Characteristic}

Age on admission (year)

Gender

Side

aStudent's t-test, 'Pearson's $\chi 2$ test, * $p<0.05$, SD: standard deviation

\begin{tabular}{|l|l|}
\hline Minimum-maximum & Study group (23 patients) \\
\hline (Mean \pm SD) & $81 \pm 6.26$ \\
\hline Female/male & $12 / 11$ \\
\hline Right/left & $10 / 13$ \\
\hline
\end{tabular}

Study group (23 patients)

68-95

$10 / 13$

\begin{tabular}{|l|l|}
\hline Control group (70 patients) & p \\
\hline $69-96$ & $0.75^{\mathrm{a}}$ \\
\hline $82 \pm 5.7$ & $0.83^{\mathrm{b}}$ \\
\hline $33 / 37$ & $0.96^{\mathrm{b}}$ \\
\hline $33 / 37$ & \\
\hline
\end{tabular}

\section{Table 2. Comparative analyses of clinical and radiographic outcomes between the case and control groups}

\begin{tabular}{|c|c|c|c|c|}
\hline & & Study group & Control group & $\mathbf{p}$ \\
\hline \multicolumn{5}{|l|}{ Clinical outcome measures } \\
\hline Length of hospital stay & $\begin{array}{l}\text { Min-max } \\
\text { Median-IQR }\end{array}$ & $\begin{array}{l}5-15 \\
9-6\end{array}$ & $\begin{array}{l}2-27 \\
8-2\end{array}$ & 0.103 \\
\hline Length of hospitalization in the ICU & $\begin{array}{l}\text { Min-max } \\
\text { Median-IQR }\end{array}$ & $\begin{array}{l}0-5 \\
1-0\end{array}$ & $\begin{array}{l}0-6 \\
0-1\end{array}$ & 0.095 \\
\hline Number of postoperative surgical site infections & - & 9/23 (39\%) & $5 / 65(7 \%)$ & $0.001^{* *}$ \\
\hline Type of anesthesia & Regional/general & $19 / 4$ & $54 / 16$ & 0.32 \\
\hline Dementia & & $9 / 23(39 \%)$ & $7 / 70(10 \%)$ & $0.003^{*}$ \\
\hline ASA & $\begin{array}{l}\text { ASA 1-2 } \\
\text { ASA 3-4 }\end{array}$ & $\begin{array}{l}8(34.8 \%) \\
15(65.2 \%)\end{array}$ & $\begin{array}{l}32(45.7 \%) \\
38(54.3 \%)\end{array}$ & 0.25 \\
\hline \multicolumn{5}{|l|}{ Radiographic outcome measures } \\
\hline Acetabular abduction angle & $\begin{array}{l}\text { Min-max } \\
\text { Median-IQR }\end{array}$ & $\begin{array}{l}29-43 \\
35-9\end{array}$ & $\begin{array}{l}28-44 \\
33.5-8\end{array}$ & 0.076 \\
\hline Center-edge angle & $\begin{array}{l}\text { Min-max } \\
\text { Mean } \pm S D\end{array}$ & $\begin{array}{l}30-52 \\
40.78 \pm 6.01\end{array}$ & $\begin{array}{l}32-54 \\
43.49 \pm 5.06\end{array}$ & $0.037 *$ \\
\hline Femoral offset & $\begin{array}{l}\text { Min-max } \\
\text { Mean } \pm S D\end{array}$ & $\begin{array}{l}20-47 \\
32.74 \pm 7.2\end{array}$ & $\begin{array}{l}20-47 \\
35.76 \pm 5.88\end{array}$ & $0.047 *$ \\
\hline Limb length discrepancy (mm) & $\begin{array}{l}\text { Min-max } \\
\text { Median-IQR }\end{array}$ & $\begin{array}{l}0-13 \\
1.1-1.8\end{array}$ & $\begin{array}{l}0-15 \\
1.9-1.93\end{array}$ & 0.28 \\
\hline
\end{tabular}




\section{Multivariate Analysis}

Variables identified as statistically significant at a $p$ value of 0.05 in the univariate model were included in the multivariate logistic regression to measure their effects on the development of hip BHA dislocation. The multivariate model found the following two significant independent variables that were strongly associated with the risk of developing dislocation: infection and dementia (Table 3).

\section{Discussion}

The results of this study indicated an incidence of dislocation of $9.5 \%$ after cementless BHA through the posterior approach in elderly patients with displaced femoral neck fractures. Multivariate logistic regression revealed a possibly increased risk for BHA dislocation associated with the development of postoperative site infection and the presence of dementia in these patients.

The dislocation incidence of $9.5 \%$ obtained in the current study is comparable with previous reports indicating an incidence of dislocation after BHA ranging from $1 \%$ to $11 \%(6,14,15)$. However, the literature remains controversial regarding the risk factors that play a role in the development of dislocation after BHA in elderly patients. Several studies have revealed different risk factors ranging from patient-related factors (e.g., history of neurological disease and weakness in the abductor muscles) to surgery-related factors (e.g., choice of surgical approach and prosthesis type) $(6-8,16)$. A prospective cohort study by Enocson et al. (16) on 739 consecutive hips determined that the posterior approach is the only factor associated with a significantly increased risk of dislocation. A study by Kim et al. (6) reported that patients with a CE angle $\leq 44^{\circ}$ were significantly more prone to develop dislocation than patients with a CE angle $>44^{\circ}$. Similarly, Zhang et al. (2) found a significant association between a CE angle $\leq 45.4^{\circ}$ and dislocation after BHA. In our study, although we found that the CE angle is significantly lower in the group with dislocation after BHA than in the control group after univariate analysis, we did not find a significant relationship between these parameters during multivariate logistic regression analysis. Mukka et al. (14) stated that, in addition to a smaller CE angle, the shortening of the FO and a shorter leg could increase the dislocation rate by decreasing the tension in peripheral soft tissues. In the present case, we found no significant association between either the FO or LLD and the development of dislocation.

In addition to radiographic parameters, various clinical parameters have been investigated as possible risk factors for the development of dislocation after BHA. For example, Mukka et al. (14) reported that mental status is more likely to be associated with dislocation than age, gender, ASA score, or other factors. Similarly, Madanat et al. (8) determined that dislocation is not associated with age, gender, BMI, dementia, alcohol consumption, living environment, operation time, or operator experience. Similar to Mukka et al. (14) but in contrast to Madanat et al. (8), our logistic regression analysis identified dementia as an independent risk factor for the development of dislocation following BHA. However, in agreement with both studies, we also observed no association between dislocation and other clinical factors, such as age, gender, side of operation, type of anesthesia, ASA score, length of hospital stay, and length of hospitalization in the ICU.

The effect of cement use during hemiarthroplasty on the risk of dislocation remains a controversial issue. Some authors have reported that the use of a cemented stem increases the risk of dislocation (15), while others have determined that stem fixation decreases the dislocation risk (17). In our study, because BHA prostheses were implanted in all patients without the use of cement, we were unable to compare the outcomes of the cementless and cemented techniques. Nonetheless, our reported rate of dislocation is similar to the rates cited in the previous studies discussed above.

Hemiarthroplasty is a popular treatment option for hip fractures in the elderly population; however, many factors that can affect dislocation may occur concomitantly in elderly patients because of the high number of comorbidities that generally accompany aging. For example, muscular dystrophy, cerebrovascular disease, chronic alcoholism, drug use, muscle coordination, and balance disorders may affect the risk of dislocation. Thus, careful examination of the patient's comorbidities during the preoperative period may be helpful in reducing the risk of dislocation following hemiarthroplasty. Surgical technique errors that may cause dislocation, such as component malposition, implant selection, and the surgeon's experience, are other factors that require separate investigations.

Table 3. Results of multivariate logistic regression analysis

\begin{tabular}{|c|c|c|c|c|c|c|c|}
\hline & & B & S.E. & Wald & df & Sig. & $\operatorname{Exp}(B)$ \\
\hline \multirow{9}{*}{ Step 1} & Length of hospital stay & -0.059 & 0.086 & 0.480 & 1 & 0.489 & 0.942 \\
\hline & Length of hospitalization in the ICU & -0.276 & 0.255 & 1.175 & 1 & 0.278 & 0.759 \\
\hline & Number of postoperative surgical site infections & 1.511 & 0.775 & 3.801 & 1 & $0.051^{*}$ & 4.530 \\
\hline & Dementia & 1.634 & 0.711 & 5.278 & 1 & $0.022^{*}$ & 5.123 \\
\hline & ASA & 0.091 & 0.631 & 0.021 & 1 & 0.885 & 1.096 \\
\hline & Acetabular abduction angle & -0.112 & 0.067 & 2.752 & 1 & 0.097 & 0.894 \\
\hline & Center-edge angle & 0.091 & 0.060 & 2.309 & 1 & 0.129 & 1.095 \\
\hline & Femoral offset & 0.008 & 0.052 & 0.025 & 1 & 0.875 & 1.008 \\
\hline & Constant & -0.772 & 4.060 & 0.036 & 1 & 0.849 & 0.462 \\
\hline
\end{tabular}




\section{Study Limitation}

The present study included several limitations that must be considered when interpreting the results. First, this study has a relatively small sample size, which limits the power of the results. However, the power was strengthened by the use of a nested case-control design, which is often adopted when the outcome is rare or when the feature of interest is difficult to obtain. In the current study, we performed a 1:3 ratio nested case-to-control study. For each dislocation patient, we matched three control patients in terms of age and sex to eliminate several confounding factors and increase the reliability of the study.

\section{Conclusion}

Evidence from this study showed that postoperative surgical site infection and dementia are independent risk factors for hip dislocation following BHA in elderly patients with displaced femoral neck fractures. Further controlled, randomized, prospective studies are needed to confirm the feasibility and effectiveness of cementless stem fixation in BHA.

Ethics Committee Approval: The approval form the University of Health Sciences Turkey, İstanbul Training and Research Hospital Local Ethics Committee was obtained (approval number: 2657, date: 08.01.2021).

Informed Consent: Written informed consent was obtained from all participants prior to their participation in this study.

Peer-review: Externally and internally peer-reviewed.

Authorship Contributions: surgical and Medical Practices - F.B., Y.Ö.; Concept - F.B., Y.Ö.; Design - F.B., Y.Ö.; Data Collection or Processing F.B., M.D., Y.B.; Analysis or Interpretation - F.B., M.D., Y.B.; Literature Search - F.B., M.D., Y.B., Y.Ö.; Writing - F.B., M.D., Y.Ö.

Conflict of Interest: No conflict of interest was declared by the authors.

Financial Disclosure: The authors declared that this study received no financial support.

\section{References}

1. Lieberman JR, Romano PS, Mahendra G, Keyzer J, Chilcott M. The treatment of hip fractures: variations in care. Clin Orthop Relat Res 2006; 442: 239-44.

2. Zhang Y, Yao Z, Shi P, Wang C, Liu J, Yang Y, et al. Morphological risk factors associated with dislocation after bipolar hemiarthroplasty of the hip in patients with femoral neck fractures-a nested case-control study. J Orthop Surg Res 2019; 14: 395.

3. Keating J, Grant A, Masson M, Scott NW, Forbes JF. Displaced intracapsular hip fractures in fit, older people: a randomised comparison of reduction and fixation, bipolar hemiarthroplasty and total hip arthroplasty. Health Technol Assess 2005; 9: 1-65.

4. Sierra RJ, Schleck CD, Cabanela ME. Dislocation of bipolar hemiarthroplasty: rate, contributing factors, and outcome. Clin Orthop Relat Res 2006; 442: 230 8.

5. Figved W, Opland V, Frihagen F, Jervidalo T, Madsen JE, Nordsletten L. Cemented versus uncemented hemiarthroplasty for displaced femoral neck fractures. Clin Orthop Relat Res 2009; 467: 2426-35.

6. Kim Y, Kim JK, Joo IH, Hwang KT, Kim YH. Risk Factors Associated with Dislocation after Bipolar Hemiarthroplasty in Elderly Patients with Femoral Neck Fracture. Hip Pelvis 2016; 28: 104-11.

7. Li L, Ren J, Liu J, Wang H, Sang Q, Liu Z, et al. What Are the Risk Factors for Dislocation of Hip Bipolar Hemiarthroplasty Through the Anterolateral Approach? A Nested Case-control Study. Clin Orthop Relat Res 2016; 474: 2622-9.

8. Madanat R, Mäkinen TJ, Ovaska MT, Soiva M, Vahlberg T, Haapala J. Dislocation of hip hemiarthroplasty following posterolateral surgical approach: a nested case-control study. Int Orthop 2012; 36: 935-40.

9. Bell K, Clement N, Jenkins P, Keating J. A comparison of the use of uncemented hydroxyapatite-coated bipolar and cemented femoral stems in the treatment of femoral neck fractures: a case-control study. Bone Joint J 2014; 96: 299-305.

10. DeAngelis JP, Ademi A, Staff I, Lewis CG. Cemented versus uncemented hemiarthroplasty for displaced femoral neck fractures: a prospective randomized trial with early follow-up. J Orthop Trauma 2012; 26: 135-40.

11. Khan R, MacDowell A, Crossman P, Keene G. Cemented or uncemented hemiarthroplasty for displaced intracapsular fractures of the hip--a systematic review. Injury 2002; 33: 13-7.

12. Ning GZ, Li YL, Wu Q, Feng SQ, Li Y, Wu QL. Cemented versus uncemented hemiarthroplasty for displaced femoral neck fractures: an updated metaanalysis. Eur J Orthop Surg Traumatol 2014; 24: 7-14.

13. Owens WD, Felts JA, Spitznagel EL Jr. ASA physical status classifications: a study of consistency of ratings. Anesthesiology 1978; 49: 239-43.

14. Mukka S, Lindqvist J, Peyda S, Brodén C, Mahmood S, Hassany $\mathrm{H}$, et al. Dislocation of bipolar hip hemiarthroplasty through a postero-lateral approach for femoral neck fractures: A cohort study. Int Orthop 2015; 39: 1277-82.

15. Varley J, Parker MJ. Stability of hip hemiarthroplasties. Int Orthop 2004; 28: 274-7.

16. Enocson A, TidermarkJ, Törnkvist H, Lapidus LJ. Dislocation of hemiarthroplasty after femoral neck fracture: better outcome after the anterolateral approach in a prospective cohort study on 739 consecutive hips. Acta Orthop 2008; 79: 211-7.

17. Salem K, Shannak O, Scammell B, Moran C. Predictors and outcomes of treatment in hip hemiarthroplasty dislocation. Ann R Coll Surg Engl 2014; 96: 446-51. 